\title{
A tale of two inositol trisphosphates
}

\author{
Robin Irvine
}

Department of Pharmacology, Tennis Court Road, Cambridge CB2 1PD, UK

\begin{abstract}
$\underline{\text { Abstract }}$
Between spring 1982 and autumn 1984 the physiological role of inositol 1,4,5trisphosphate as a calcium-mobilising second messenger was first suggested and then experimentally established. At the same time the unexpected complexity of inositide metabolism began to be exposed by the discovery of inositol 1,3,4-trisphosphate. This article recalls my entanglement with these two inositol phosphates.
\end{abstract}

Introduction (2015)

This is a personal recollection of events surrounding some scientific discoveries that took place in what were for me two and a half remarkable years, from spring 1982 to autumn 1984. During this time the second messenger function of inositol 1,4,5trisphosphate $\left(\operatorname{Ins}(1,4,5) P_{3}\right)$ was established, from first suggestions right through to moreor-less universal acceptance. The period also included the discovery and elucidation of the isomeric configuration of inositol 1,3,4-trisphosphate $\left(\operatorname{Ins}(1,3,4) P_{3}\right)$, which, as the account below shows, also occupied much of my attention. From a $21^{\text {st }}$ Century perspective (e.g. [1]), it can be seen that the real significance of $\operatorname{Ins}(1,3,4) P_{3}$ is as the starting point of the unexpected and awesome proliferation of inositol phosphates and lipids and their functions that ensued in the 80's and 90's [2,3]. But at the time its discovery, although implying that things were more complicated than we thought, was really just another facet of the story of $\operatorname{Ins}(1,4,5) P_{3}$, with which it was inextricably entwined.

This account was originally hand-written in a single session during an unscheduled eight hour wait in an airport (Detroit, I think) in 1987. I had exhausted my stamina for reading and while drinking a beer or two fell to musing over what had happened over the previous hectic few years; to alleviate the interminable waiting I wrote it all down. I came across the pile of hand-written pages during an office clear-out when I changed jobs in 1996 and I used an excerpt of it as the basis for a short article about the discovery of Ins $(1,3,4,5) P_{4}[4]$. Here I have simply transcribed the rest of it. Although while doing that I have smoothed over the worst colloquialisms, removed profanities and inserted some references and a few perspectives [any $21^{\text {st }}$ Century thoughts are distinguished by being placed in square brackets], I have resisted the temptation to tidy it up into a flawless piece of prose because it is very much a personal narrative. Charles Fernyhough has argued in his book 'Pieces of Light' [5] that remembering is a flawed process even when the writing down happens shortly after the events remembered, so I should emphasise that this account is how I saw it all in 1987 and I apologise to any of the people mentioned below if they remember anything differently.

1982

The story really began for me with a meeting held at the AFRC Insitute of Animal Physiology [now the Babraham Institute] in Rex Dawson's office some time in March 1982; I've lost the diary of that year so the exact date is unknown. I had been trying for 
some months to label platelets with $\left[{ }^{3} \mathrm{H}\right]$-inositol so that I could stimulate them with thrombin and see which inositol phosphate appeared first. This experiment was inspired by, and was designed to test, the proposition (which was in turn a resurrection of an earlier idea [6]) that we had heard the previous autumn from Bob Michell's group at a meeting at the Royal Society in London: that PtdIns $(4,5) P_{2}$, not PtdIns, might be the primary target for receptor-mediated stimulated inositol lipid turnover [7]. The experiment failed completely (not surprisingly, as platelets take up inositol very poorly and you need financial resources beyond ours to succeed!) and as that was the only cell system I had up and running I had more or less given up on the whole question. Bernie Agranoff and his colleagues did succeed in doing this in platelets around the same time, but used the more heroic approach of $\left[{ }^{32} P\right.$ ] labelling [8].

That March, Rex and I received a phone call from Mike Berridge down in Cambridge saying that he and Pete Downes had been collaborating doing more or less the same thing in other tissues (which took up $\left[{ }^{3} \mathrm{H}\right]$-inositol much better than platelets did), but were in a bit of confusion in trying to identify what was what. Mike and I had recently collaborated on a joint project looking at products that resulted from PtdIns hydrolysis by phospholipases secreted by blowfly salivary glands [9] so we were each aware of each other's respective expertise in $\mathrm{Ca}^{2+}$ (Mike) and inositides (me). I had never met Pete, though I knew his name from his publications. He was that day in March wearing a jumper identical to mine and as we are superficially similar in appearance a number of people in the Department took us for brothers; we couldn't decide which of us was most insulted. At that meeting it was decided that I would analyse by our various analytical techniques the ammonium formate eluates from Mike and Pete's Dowex columns, and also their unprocessed cell extracts. Together we hoped that we could produce the first report of different Ins $P$ s produced by various cells, which would be as definitive as possible with well-characterised compounds - a laudable aim that almost succeeded.

It took quite a few months and many scintillation vials (cutting paper ionophoretograms into strips has that inevitable consequence) to do it all. There was a hold-up for about two months because the Ins $P_{2}$ that parotid glands were producing would not co-chromatograph in a paper chromatography system with the Ins $P_{2}$ standard that we had. Neville Clarke, Rex's technician, had produced this $\operatorname{Ins} P_{2}$ standard by acid hydrolysis of purified PtdIns4P from brain, so this result was not entirely surprising when we thought about it: in an acid hydrolysate there will be little if any of the 1,4 isomer of Ins $P_{2}$ present due to acid-catalysed phosphate migration [10]. It was not until eventually I managed to make a small quantity of $\left[{ }^{32} P\right] \operatorname{Ins}(1,4) P_{2}$, prepared enzymatically from red cells, that we could convince ourselves that parotid glands were producing the right stuff; that turned out to be a critically useful lesson in isomers (see below).

The delay was not entirely wasted, as during this time Pete had talked with a neighbour, Bill Schwartz in the MRC Laboratory of Molecular Biology, who had an FPLC system up and running (one of the first in the U.K., as this technology had only been launched the year before). Pete persuaded Bill to put a parotid gland extract onto a MonoQ column and by using acetate instead of formate they managed to achieve the lovely sharp peaks that only a high-performance system can give. Pete and I agreed that it would make a nice pretty picture to put in the Biochem $J$ paper we were planning [11] if we added some of the $\left[{ }^{32} P\right] \operatorname{Ins}(1,4) P_{2}$ and $\left[{ }^{32} P\right] \operatorname{Ins}(1,4,5) P_{3}$ I had made from red cells to the tritium-labelled parotid extract, and we could then show a beautiful cochromatography of the two isotopes. Unfortunately (or fortunately with hindsight) the experiment backfired, as in the Ins $P_{3}$ region of the column eluate we could not persuade 
the tritium (from the parotid Ins $P_{3}$ ) and the $\left[{ }^{32} P\right]$ (from the red cells) to co-elute exactly, and in the end we had to leave out the planned Figure (Fig 1) and put in a Table instead! That was something we would have to look at further.

Shortly afterwards I ran some of the parotid $\operatorname{Ins} P_{3}$ on a paper chromatographic system with $\left[{ }^{32} P\right] \operatorname{Ins} P_{3}$ from red cells and put it down to autoradiograph for a week or two. The first thing that Dave Lander did when he was transferred to my lab in early 1983 as an additional technician to Andy Letcher (both were stalwart participants in this entire story) was to develop the film and cut up the paper. As on the Mono Q column, the $\left[{ }^{32} P\right]$ and $\left[{ }^{3} \mathrm{H}\right]$ were not co-chromatographing and this diminished any thoughts we had had of isotopic artefacts (e.g. tritium in the inositol ring altering the chromatographic behaviour of the $\operatorname{Ins} P_{3}$ ) - something odd was going on.

Meanwhile, the manuscript describing the characterisation of the inositol phosphates in the various tissues [11] was prepared and submitted, Pete left Cambridge to take up a post-doc position at ICI in Cheshire, and Mike set about his elegant time-course experiments [12] using the techniques we had now characterised and verified. I, reluctantly, had to spend four months or so repeating some experiments on 'PtdIns phosphodiesterase' (which we now know is actually PI-PLC [13]) to sort out a confusion that had emerged from earlier work in the lab [14]. I should also add that the $\left[{ }^{32} P\right]$ labelled Ins $P_{2}$ and $\operatorname{Ins} P_{3}$ we made from red cells were merely by-products of the radioactive PtdIns $(4,5) P_{2}$ that we were routinely making as a part of our studies in which we showed that 'PtdIns $(4,5) P_{2}$ phosphodiesterase' was probably the same enzyme as 'PtdIns phosphodiesterase', but under physiological conditions and with a membrane substrate it had a high specificity for PtdIns $(4,5) P_{2}[15]$. These experiments were also going on throughout ' 82 and ' 83 - they were busy years!

Towards the end of 1982, Mike, inspired by his kinetic experiments [12], which suggested that Ins $(1,4,5) P_{3}$ is an early, possibly primary, product of inositide turnover, thought about testing his hypothesis that it might be the second messenger responsible for $\mathrm{Ca}^{2+}$ mobilisation. He tried two approaches. He sent some Ins $P_{3}$ to Bob McBurney in Newcastle to inject into a neurone or two, which Bob duly did; not a lot happened [actually, injecting Ins $(1,4,5) P_{3}$ into neurones often has little effect]. Also, in December 1982 Mike went to a meeting in Amsterdam where he heard Irene Schülz describe the permeabilised pancreatic cell preparation that she and Hans-Peter Streb had set up in Frankfurt [16], and he realised that this was an excellent system in which to test Ins $P_{3}$ 's second messenger role.

\section{$\underline{1983}$}

The permeabilised pancreatic acinar cell preparation, however, was also a blank, as Mike ruefully explained to me when I visited him in Cambridge one day in February '83. When I asked where the Ins $P_{3}$ came from he explained that it was from Neville Clarke. I told Mike that this would be an old standard prepared by acid hydrolysis of PtdIns $(4,5) P_{2}$ and reminded him of my previous problem with an $\operatorname{Ins} P_{2}$ standard from the same source. I pointed out that it was entirely possible that because of acid-catalysed phosphate migration there may be virtually no 1,4,5 isomer in Neville's Ins $P_{3}$ and that if this was to be a second messenger, some kind of isomeric specificity seemed likely; it would be reasonable to try again using pure $\operatorname{Ins}(1,4,5) P_{3}$. At this he brightened and asked if I could make some of the genuine article. This I did, from human red cells using Pete Downes' method [17]. We had previously only used this method to make our radioactive Ins $(1,4,5) P_{3}$, but I was pleased to find that we derived a reasonable mass (about 1-2 
$\mu$ moles $)$ of Ins $(1,4,5) P_{3}$ from a pint of blood, which looked pure on ionophoretograms, and we sent the first batch to Irene towards the end of February.

Mike has since recalled [18] that we received an excited phone call from Irene almost immediately, but in fact there was a long delay. Irene did phone to say that the sample had arrived, but it had been lost because the tube looked empty; Mike told her it was invisible and probably very potent, so just add water to the tube and proceed! (Joel Brown described to me a similar reaction when he was first given an "invisible" sample of Ins $(1,4,5) P_{3}$ to test on Limulus photoreceptors - it made the effects of the "solution" all the more spectacular.) I recall chatting one day in early April with Mike and Tim Rink, in Tim's lab in Cambridge, and glumly agreeing that no news from Irene was bad news and that it looked like another good idea had gone west. Then, later that month, Mike did indeed get a highly excited phone call - Irene was already drafting a manuscript as a result of a clear and potent effect of the Ins $P_{3}$, which mobilised $\mathrm{Ca}^{2+}$ in their system.

This produced a bit of a panic in Mike and me, as the prospect of artefacts of one sort or another loomed large. So during the first few weeks of May I prepared ten samples to send to Hans-Peter and Irene, which were controls of one sort or another (e.g. a blank Ins $P_{3}$ preparation prepared by omitting the $\mathrm{Ca}^{2+}$ from the incubation of the red cell ghosts that liberates the Ins $P_{3}$; phosphatase-treated $\operatorname{Ins} P_{3}$; various other inositol phosphate samples that I had made during the preceding eight years in Rex's lab; etc). I numbered these and Mike sent them "blind" to Frankfurt for testing. One pair of samples I decided to re-number (because I had accidentally inverted my logical numbering sequence for that particular pair) after I had photocopied the "key" for Mike, so only I knew they were interchanged. This was not a deliberate trick - I did it without thinking but when later they were the only two which gave the "opposite" result to what was expected (to the disappointment of Irene, Hans-Peter and Mike) it gave us all a great boost in confidence when I revealed the change!

Mike was burning with impatience to get the manuscript off as he feared that if it was not published in 1983 it would get lost in a rush of 1984 publications (how right he was!) and when we submitted a manuscript to Nature in June we were still not entirely convinced of the inactivity of $\operatorname{Ins}(1,4) P_{2}$ - it is very difficult to prepare really clean Ins $(1,4) P_{2}$ from red cells using the techniques I had. But by the time the manuscript came back with favourable referees comments (although worries about the specificity were expressed), I had, after a struggle, made an $\operatorname{Ins}(1,4) P_{2}$ prep that I was really happy with. It was unambiguously $\operatorname{Ins}(1,4) P_{2}$ and was $>98 \%$ pure, and this preparation was only $1 \%$ as potent as Ins $(1,4,5) P_{3}$ (so even that small effect was probably due to contamination with the latter). I also had made an Ins $P_{3}$ preparation that had been acid-treated (to randomise the phosphate moieties - see above), which I repurified and re-assayed for phosphorus, and Hans-Peter found that this was clearly much less potent than $\operatorname{Ins}(1,4,5) P_{3}$, implying that at least some isomeric specificity was operating. We were at last happy with the revised version, and as it finally appeared [19] [and reading it afresh now] it represents a very convincing case that $\operatorname{Ins}(1,4,5) P_{3}$ was indeed a very promising candidate to be the mediator of intracellular $\mathrm{Ca}^{2+}$ mobilisation.

Meanwhile, work on the Ins $P_{3}$ from parotid glands was still progressing. I mixed this $\left[{ }^{3} \mathrm{H}\right] \operatorname{Ins} P_{3}$ with the $\left[{ }^{32} P\right] \operatorname{Ins} P_{3}$ from red cells and presented the mixture to the red cell 'ghosts', which contain an Ins $P_{3}$ phosphatase that Pete Downes had discovered earlier as part of his Ph.D. [17]. Even when all the Ins $P_{3}$ from the red cells had been hydrolysed, a majority of the tritiated Ins $P_{3}$ was untouched, and this was the final straw that convinced me that we really did have a new compound to deal with. I already knew that it was an $\operatorname{Ins} P_{3}$ because if I dephosphorylated it with alkaline phosphatase it yielded tritiated 
inositol rather than glucose, gluconurate etc. In June 1983 I attended a meeting in Harrison Hot Springs in Canada. This was memorable not least for an amazing birdwatching trip in a speed boat with Pete and Bob Michell, and also (while I was away) a child visiting our home walked right through a glass door (unscathed, to my wife Sandi's enormous relief!). At the meeting Bill Sherman, Pete and I discussed what the mystery $\operatorname{Ins} P_{3}$ might be. We agreed that the likeliest bet was $\operatorname{Ins}(2,4,5) P_{3}$, formed by acidquenching of cyclic Ins $(1: 2,4,5) P_{3}$, which we predicted might be present as a parallel with the cyclic Ins $(1,2) P$ known to be formed during hydrolysis of PtdIns by PI-PLC [20]. [Much later, some cyclic $\operatorname{Ins} P_{3}$ was found by Majerus' group in stimulated tissues [21].]

During this time I re-read, in much more detail than before, Clinton Ballou's classic papers $[22,23]$, which had established the structure of $\operatorname{Ins}(1,4,5) P_{3}$ (using heroic amounts of material extracted from $100+$ cow brains!). There were three reasons for reading these papers again. Firstly, if we followed Ballou's methods we would get much more material than we obtained from red cells, and so we would reduce the continuous stream of preparations using expired blood obtained from the very helpful Roger Pepper at the Cambridge Blood Transfusion Centre. We could also prepare $\operatorname{Ins}(2,4,5) P_{3}$, a byproduct in the preparation $[22,23]$, at the same time, which would enable us to see if the mystery Ins $P_{3}$ was indeed that isomer.

Secondly, with the concept of isomeric specificity firmly in my mind (see above), it seemed to me rather ironic that no sooner had we used what we believed to be a pure, defined isomer of Ins $P_{3}$ to demonstrate $\mathrm{Ca}^{2+}$ mobilisation, than we realised that we might not have any idea what that isomer actually was! We now knew there were certainly two Ins $P_{3}$ 's - one from red cells, which mobilised $\mathrm{Ca}^{2+}$ (see above), and the other, the major isomer produced in stimulated parotid slices. This produced the nightmare thought that the Ins $(1,4,5) P_{3}$ that Ballou and colleagues had studied (or, more strictly, the PtdIns $(4,5) P_{2}$ from which it was derived) may be a speciality of myelin (and hence enriched in cow brains), whereas the compound from red cells, the $\mathrm{Ca}^{2+}$ mobiliser and potential second messenger, might be an entirely different isomer. Clearly, it was imperative to repeat Ballou's extraction and separation methods exactly so that we could obtain the same compound that he did, which we could be sure was Ins $(1,4,5) P_{3}$, and test it in various $\mathrm{Ca}^{2+}$-mobilising systems.

The third reason was that I saw no particular reason why the structural determination methodology that Ballou and his colleagues had pioneered (based in turn on Fischer's original strategies) should not be applied to trace quantities of radiolabelled inositol phosphates. I reckoned that we could use careful co-chromatography with markers in a selection of independent separation methods to identify the degradation products obtained from inositol phosphates by periodate oxidation, borohydride reduction, and dephosphorylation. Thus we could in principle determine the structure of the mystery $\operatorname{Ins} P_{3}$ even if we only had a few thousand d.p.m. of radioactivity to work with. The three of us (Andy, Dave and I) began to do this (amidst all the other things we were doing, see above!) on the mystery parotid $\operatorname{Ins} P_{3}$.

Some aspects were easier said than done. We frequently lost samples when trying to desalt them because we had so little mass to work with. Also, it was extraordinarily difficult to detect non-cyclic alditols on paper after chromatography in a boric acidcontaining solvent (much the most effective method for separations) if you use silver detection; Clinton Ballou had not had that problem, as he used benzidine-containing sprays for detection, and modern safety standards forbade us even having benzidine in the lab, let alone spraying papers with an aerosol of it. The fact that Ballou had done it for 
years and was still alive and well and living in California was dismissed by the Safety Officer (quite rightly) as "anecdotal".

Ionophoresis in $\mathrm{NaOH}$, a powerful method for separating alditols invented by Frahn and Mills [24], which we adapted and found most useful, also gave us some entertainment with the large ionophoresis apparatus that we used. This was cooled with gallons of white spirit, and so was housed in a separate room equipped with a $\mathrm{CO}_{2}$ 'sprinkler' system - one whiff of smoke and the doors locked automatically, some massive lead weights dropped to hit a lever and the room was flooded with $\mathrm{CO}_{2}$ (so you had to get out fast). The $\mathrm{NaOH}$ dissolved everything in the tank over a period of time and until we introduced an all-glass apparatus we sometimes had leaks and loose electrodes to contend with, and there ensued several entertaining episodes of sparking electrodes. (The theory, calmly explained to me by Rex, is that it does not matter as long as there is no oxygen under the white spirit to ignite it, but theory is not always entirely re-assuring with an electrode cracking away merrily under a potential fireball!)

Before the November publication of Streb et al [19], the four authors of that paper met (for the first time for Hans-Peter and I) at a September meeting in Zeist, Holland, which was organized by John Williamson. The excited atmosphere at that meeting when Mike presented for the first time in public the data from the pancreatic acinar cells was extraordinary, and I can still recall it to send a thrill down my spine. The story had already by then received a strong boost by the elegant confirmation during the summer by Gillian Burgess and her colleagues in Jim Putney's lab. Mike had chatted with Jim earlier in the year, and as a result I had sent him some $\operatorname{Ins} P_{3}$. Gillian used a different technique $\left({ }^{45} \mathrm{Ca}^{2+}\right.$ and EGTA-Ca ${ }^{2+}$ buffers), a different tissue (liver) and animal (guinea pig), yet Ins $P_{3}$ did the same thing with a near identical potency. Another of my most vivid memories of the time is Mike phoning me at home (actually he had to trace me to another house where I was baby-sitting) and he was almost leaping down the phone with excitement at Jim's news.

For Jim's lab I dreamt up another control whereby they received "blind" three samples eluted from adjacent strips of a preparative electrophoretogram of Ins $P_{3}$, only one of which contained the $\operatorname{Ins} P_{3}$. Only that sample mobilised $\mathrm{Ca}^{2+}$ and did so with a potency (based on phosphorus mass) identical to the original raw material, and this was another major step towards convincing us all that there really was something in the whole idea. At the meeting in Zeist John Williamson's group also had a positive result from another sample of $\operatorname{Ins} P_{3}$, which I had sent him, and so by the end of that meeting there was little serious doubt in anyone's minds that we did indeed have a new second messenger on our hands.

Moreover, shortly after the meeting I was able to make $\operatorname{Ins}(1,4) P_{2}$ and $\operatorname{Ins}(4,5) P_{2}$ very pure by Clint Ballou's original methods (which included a three-to-four week preparative chromatography step). Hans-Peter and Irene showed the remarkable specificity of Ins $(1,4,5) P_{3}$ in a beautiful experiment employing the new super-pure $\operatorname{Ins}(1,4) P_{2}$, Ins $(4,5) P_{2}$, and (definitely genuine) $\operatorname{Ins}(1,4,5) P_{3}$, of which only the last of these had any effect at all and that was a huge release of $\mathrm{Ca}^{2+}$ (Fig 2). This particular experiment was never published as it was later superseded by more quantitative data [25], which I always thought was rather a pity, as for me especially it was a very important part of the strengthening feeling that this was no artefact. Rex and I had had some concerns about the likely ability of the two vicinal phosphates of $\operatorname{Ins}(1,4,5) P_{3}$ being able to bind $\mathrm{Ca}^{2+}$ strongly, but the low (about two orders of magnitude lower than Ins $\left.(1,4,5) P_{3}\right)$ potency of $\operatorname{Ins}(4,5) P_{2}$ was definitely reassuring. [Our concerns were that the ability of the 4 and 5 phosphates of $\operatorname{Ins}(1,4,5) P_{3}$ to bind $\mathrm{Ca}^{2+}$ could have led to artefactual changes in 
$\mathrm{Ca}^{2+}$ that were not a reflection of any physiological function. In fact because Gillian and her colleagues used buffered ${ }^{45} \mathrm{Ca}^{2+}$ efflux as an assay this possibility was highly unlikely, but that did not stop me worrying. Moreover, as noted in the legend to Figure 2, the direct demonstration in this experiment that the effect of $\operatorname{Ins}(1,4,5) P_{3}$ was catalytic was very reassuring.]

We had been progressing steadily with these larger scale preparations of inositol phosphates from bovine brain by Clint Ballou's methods (which in turn used as a starting point the original 1949 inositol lipid preparation of Jordi Folch-Pi [26] - the old ones are the best!). By the time of the Zeist meeting we had our first Ins $(1,4,5) P_{3} / \operatorname{Ins}(2,4,5) P_{3}$ mixtures ready to test the chromatographic behaviour of the latter with respect to the parotid Ins $P_{3}$ on paper. That had taken longer than necessary because of very low yields of Ins $P_{3}$ from cow brains, these low yields being due to me quenching $\mathrm{KOH}$ solutions with $\mathrm{HCl}$ before loading onto Dowex columns in the formate form. It was a while before I realised that I should be using formic acid and that the $\mathrm{Cl}^{\prime}$ was stripping the formate from the column so the Ins $P_{3}$ was not sticking; sometimes with the benefit of hindsight one's idiocy can be truly embarrassing.

We set a chromatography paper running with some of Pete's parotid Ins $P_{3}$ in it just before the Zeist meeting. Pete, by the way, was still supplying us with this at considerable trouble to himself - I don't think he was meant to be doing that at ICI, but he used to rush into the lab early to knock off a preparation of stimulated glands without them knowing and sent us the samples. That chromatogram told us unequivocally that the parotid $\operatorname{Ins} P_{3}$ was not $\operatorname{Ins}(2,4,5) P_{3}$, and we already knew it was not $\operatorname{Ins}(1,4,5) P_{3}$, so now we knew for sure that we had an entirely new compound on our hands. Now we really had to get stuck into it, with an increasing sense of urgency heightened by Pete admitting publicly (he had no option under close questioning) at the Chilton Conference in Dallas in the first week of January 1984 that the $\operatorname{Ins} P_{3}$ predominating in stimulated parotid glands was not $\operatorname{Ins}(1,4,5) P_{3}$.

\section{4}

The atmosphere at the Chilton Conference was almost as electric as that in Zeist, and during the first few months after that Andy, Dave and I spent a significant amount of our time making and checking the various inositol phosphates prepared from bovine brains, which during that year were to be added/microinjected to more cells and physiological systems than I could dream of. As the news spread around the world, especially following the publication of Streb et al [19], more and more people contacted Mike or myself (or we contacted them - just once or twice we ended up with some duplication and confusion because things were happening so fast). To these collaborators we sent some Ins $(1,4,5) P_{3}$ (plus Ins $(1,4) P_{2}$ and Ins $(4,5) P_{2}$ as the principal controls) for testing on permeabilised cells [27], membrane preparations [28, 29], and intact cells by microinjection [30-32]. Meanwhile, other (or indeed, often the same) groups were demonstrating the stimulated synthesis of $\operatorname{Ins} P_{3}$ (isomer unspecified) by a wide range of agonists on many tissues. Although there were, as there should have been, some sceptical voices, it was amazing to see how this proliferation of positive reports swept along with it an almost instantaneous acceptance that $\operatorname{Ins}(1,4,5) P_{3}$ was here to stay and in May Mike and I began to write a review for Nature [33] in which we were able to summarise a large body of work that placed $\operatorname{Ins}(1,4,5) P_{3}$ firmly on its way to established second messenger status. 
All this Ins $(1,4,5) P_{3}$ and $\operatorname{Ins} P_{2}$ production became pretty routine stuff to us in Babraham by now and my thoughts during the first months of 1984 were more often revolving around the unknown Ins $P_{3}$ from parotid glands. We had a lot of practical problems, as discussed above, and we had had more or less to re-invent the whole methodology. However, as is often the way of science, when it finally came good, it did so in a rush. Within one week in April we obtained beautiful data showing unequivocally that the mystery Ins $P_{3}$ was degrading by periodate oxidation, borohydride reduction and dephosphorylation to altritol, meaning that it was $\operatorname{Ins}(1,2,4) P_{3}$ or $\operatorname{Ins}(1,3,4) P_{3}$. We had already made several attempts, with varying degrees of failure, to hydrolyse the $\operatorname{Ins} P_{3}$ to Ins $P$ species to get independent insight into the isomeric configuration. These experiments never gave us good quantitative data - we were assuming that strong alkaline hydrolysis would cause a non-specific release of phosphate moieties, but we now know that such hydrolysis of $\operatorname{Ins}(1,3,4) P_{3}$ initially gives you mostly $\operatorname{Ins}(1,3) P_{2}$ and $\operatorname{Ins}(1,4) P_{2}$, and hardly any $\operatorname{Ins}(3,4) P_{2}$. However, what our summed data on the Ins $P$ s we derived showed clearly was that we never derived any Ins $2 P$ from the mystery $\operatorname{Ins} P_{3}$, so Ins $(1,2,4) P_{3}$ was ruled out as a possible structure, and that only left $\operatorname{Ins}(1,3,4) P_{3}$.

We submitted the manuscript to the Biochem $J$ [34] and set about trying to find out where the Ins $(1,3,4) P_{3}$ was coming from. I should add that during the time between submission and acceptance of the manuscript we had a horrendous thought that the $\left[{ }^{3} \mathrm{H}\right]$ myo-inositol might have another inositol contaminating it which could get into the lipids, and could generate an inositol trisphosphate which was not based on the myo-inositol ring; this was quickly eliminated thanks to the financial resources of ICI which enabled Pete to do a quick and very expensive $\left[{ }^{14} \mathrm{C}\right]$ inositol experiment $-\left[{ }^{14} \mathrm{C}\right]$-inositol is prepared by a method entirely different from that used to make $\left[{ }^{3} \mathrm{H}\right]$-inositol.

As for where the Ins $(1,3,4) P_{3}$ was coming from, within weeks of resolving the structure of $\operatorname{Ins}(1,3,4) P_{3}$ we also came within an inch of finding its origin by almost discovering both $\operatorname{Ins}(1,3,4,5) P_{4}$ and $\operatorname{Ins}(1,4,5) P_{3} 3$-kinase (see Fig 3). In early 1984 HansPeter, Irene and I had done some experiments following the degradation of $\operatorname{Ins}(1,4,5) P_{3}$ in permeabilised pancreatic acinar cells (to see if that degradation coincides with the reuptake of $\left.\mathrm{Ca}^{2+}\right)$. We found that $\operatorname{Ins}(1,4,5) P_{3}$ was converted by the cells in an ATPdependent manner into an "Ins $P_{3}$ " which was resistant to the phosphatase in red cell 'ghosts'. If we had had $\left[{ }^{3} \mathrm{H}\right]-\operatorname{Ins}(1,4,5) P_{3}$ available then, the whole thing would have been cracked, but our $\left[{ }^{32} P\right]$-Ins $(1,4,5) P_{3}$ that I sent to Germany was home-made, labelled mostly in the 5-phosphate, and I found that some of the inorganic phosphate released was re-incorporated into ATP. Thus when I examined the putative 5-phosphatase-resistant Ins $P_{3}$ it was mostly ATP, and the small amount of Ins $P_{3}$ which was left (which must have been Ins $(1,3,4) P_{3}$ generated in the test tube) I interpreted as being the last remnants of the $\left[{ }^{32} P\right]$-Ins $(1,4,5) P_{3}$ that we had originally added. This is yet another example of hindsight making things clearer, but I also remember that my thinking was not as sharp in April/May 1984 as it might have been owing to the unbelievably hectic rate at which things were happening scientifically (see above), plus a conference trip to Switzerland, Sandi having an operation, and right in the middle of it all (in the early hours of the morning that I left for Switzerland) my younger son being hospitalised with an unexpected attack of croup. Maybe without that lot the penny would have dropped!

We were very keen to find a way of separating the 1,3,4 and 1,4,5 isomers and tried all kinds of chromatographic strategies. A great stroke of luck came with the presence of Erik Änggård in the lab, on sabbatical leave from the Karolinska Institute, who was familiar with hplc, and it was he who shut himself away with the (only) hplc machine at Babraham on the far side of the Institute and eventually obtained good sharp 
resolutions of adenine nucleotides on a Partisil SAX column. We then tried our two Ins $P_{3}$ s on his system, and achieved a beautiful baseline separation (improved shortly afterwards by me, accidentally making up the eluant to the wrong $\mathrm{pH}$ ). It was unfortunate that despite strenuous efforts (and help from Hal Dixon) we could not avoid having inorganic phosphate in the eluant (thus making difficult any mass measurement by phosphate analysis). But it was a fine separation, which we published the following year [35]. [Although variations have been played on it since, it has remained one of the most widely-used procedures for separating inositol phosphate isomers and deacylated inositol lipids.]

Much of the data for ref [35] had been generated by the time our Nature review [33] appeared, so the tale of the two inositol trisphosphates remained closely entwined until the end of 1984. Indeed, I regard the elucidation of the isomeric configuration of $\operatorname{Ins}(1,3,4) P_{3}$ and the development of a way of separating it from $\operatorname{Ins}(1,4,5) P_{3}$ as being an important part of the Ins $(1,4,5) P_{3}$ saga for two reasons additional to the fact that the stories were exactly contemporaneous. Firstly, even in those early days it was evident that the kinetics of ' $I n s P_{3}$ ' production and particularly its disappearance after stimulation (e.g. [36]) were often far from compatible with its proposed second messenger function (see also Robin Hesketh's News and Views on Streb et al [37]). Separate analysis of the 1,4,5 isomer soon removed most of these kinetic concerns [35, 38]. Secondly, even though we had no idea where Ins $(1,3,4) P_{3}$ was coming from, nor why it was there, the facts that we knew what it was, that we could separate it from $\operatorname{Ins}(1,4,5) P_{3}$, and that Ins $(1,4,5) P_{3}$ was definitely the $\mathrm{Ca}^{2+}$ mobiliser, prevented a potential nightmare of confusion happening just as people were trying to take on board the idea of $\operatorname{Ins}(1,4,5) P_{3}$ as a second messenger. So I always felt that the (comparative) clarification that resulted from our work on Ins $(1,3,4) P_{3}$ helped a great deal towards the ensuing rapid acceptance of Ins $(1,4,5) P_{3}$ 's function. The astonishing pace with which things moved following Streb et al [19] is best illustrated by the fact that the 'definitive' review that Mike and I wrote on Ins $(1,4,5) P_{3}$ as a second messenger for Nature [33] was published only one year and two weeks after those original observations [19].

\section{Postscript (2015)}

Of course, in the autumn of 1984 there was still a long way to go. Many of the experimental procedures with which we had grappled became routine techniques for us and others in the ensuing years (e.g. [39-45]). For me the hectic pace described above continued into 1985 when we discovered $\operatorname{Ins}(1,3,4,5) P_{4}$ and determined its isomeric configuration $[4,39]$. At the same time, the hplc separation technique set up to analyse the two Ins $P_{3}$ s and Ins $P_{4}$ began to reveal that higher inositol phosphates (e.g. Ins $P_{5}$ and $\operatorname{Ins} P_{6}$ ) were ubiquitous in eukaryotes rather than a speciality of the plant kingdom or erythrocytes of a few vertebrate species $[2,46]$. Then the discovery of $\operatorname{Ins}(1,4,5) P_{3} 3$ kinase [40] not only completed the $\operatorname{Ins} P_{3} / \operatorname{Ins} P_{4}$ pathway (Fig 3) but enabled us to make Ins $(1,3,4,5) P_{4}$ to test on experimental systems. The unravelling of the function of Ins $(1,3,4,5) P_{4}$ has been a much longer and more tortuous path and we are only just beginning to see the light of some understanding now [47, 48]. Appreciation of the functions of some other higher inositol phosphates has proceeded at a much faster pace (e.g. [49-52]) and they continue to surprise us. Meanwhile, many aspects of the inositol lipid story have become well established, especially the 3-phosphorylated lipids, but there are still a huge number of unanswered questions to keep us all busy for decades to come (see ref [53] for a magisterial summary of the current state of play). 
All this in itself serves to emphasise the remarkable rapidity with which Ins $(1,4,5) P_{3}$ was accepted and then entered the textbooks. It is certainly unlikely that I will be involved again in such an exhilarating and frantic two and a half years as those described above. I can't say I'm entirely sorry that life is now a bit quieter!

Acknowledgements

R.I. is a Royal Society Research Professor. All of the work done at Babraham (and in Mike Berridge's lab in Cambridge) during 1982-4 was supported by the AFRC (now the BBSRC) - no grants, no reports or assessments, and certainly no 'impact factors'; just getting on with the science.

\section{References}

1 Irvine, R. F. (2003) Timeline: 20 years of $\operatorname{Ins}(1,4,5) \mathrm{P}_{3}$, and 40 years before. Nat. Rev. Mol. Cell. Biol. 4, 580-5855.

2 Irvine, R. F. and Schell, M. J. (2001) Back in the water: the return of the inositol phosphates. Nat. Rev. Mol. Cell Bio. 2, 327-338

3 Vanhaesebroeck, B., Leevers, S. J., Ahmadi, K., Timms, J., Katso, R., Driscoll, P. C., Woscholski, R., Parker, P. J. and Waterfield, M. D. (2001) Synthesis and Function of 3-Phosphorylated Inositol Lipids. Annu. Rev. Biochem. 70, 535-602. 4 Irvine, R. F. (1997) Xylitol or bust. trp3 (Wellcome News). Issue 10 (Q1), 30

5 Fernyhough, C. (2012) Pieces of light. Profile Books, London.

6 Durell, J. and Garland, J. T. (1969) Acetylcholine-stimulated phosphodiesteratic cleavage of phosphoinositides: hypothetical role in membrane depolarization. Ann. N.Y. Acad. Sci. 165, 743-754

7 Michell, R. H., Kirk, C. J., Jones, L. M., Downes, C. P. and Creba, J. A.

(1981) The stimulation of inositol lipid metabolism that accompanies calcium mobilization in stimulated cells: defined characteristics and unanswered questions. Philos. Trans. Roy. Soc. Lond. B Biol. Sci. 296, 123-138

8 Agranoff, B. W., Murthy, P. and Seguin, E. B. (1983) Thrombin-induced phosphodiesteratic cleavage of phosphatidylinositol bisphosphate in human platelets. J Biol Chem. 258, 2076-2078

9 Irvine, R. F., Berridge, M. J., Letcher, A. J. and Dawson, R. M. C. (1982) Phosphatidylinositol-hydrolysing enzymes in blowfly salivary glands. Biochem J. 204, 361-364

10 Pizer, F. L. and Ballou, C. E. (1959) Studies on myo-inositol phosphates of natural origin. J. Am. Chem. Soc. 81, 915-921

11 Berridge, M. J., Dawson, R. M., Downes, C. P., Heslop, J. P. and Irvine, R. F. (1983) Changes in the levels of inositol phosphates after agonist-dependent hydrolysis of membrane phosphoinositides. Biochem. J. 212, 473-482

12 Berridge, M. J. (1983) Rapid accumulation of inositol trisphosphate reveals that agonists hydrolyse polyphosphoinositides instead of phosphatidylinositol. Biochem. J. 212, 849-858

13 Rhee, S. G. and Choi, K. D. (1992) Regulation of phospholipid-specific phospholipase C isoforms. J Biol Chem. 287, 12393-12396

14 Irvine, R. F. and Dawson, R. M. (1983) Phosphatidylinositol phosphodiesterase of rat brain: $\mathrm{Ca}^{2+}$-dependency, $\mathrm{pH}$ optima and heterogeneity. Biochem J. 215, 431-432 
15 Irvine, R. F., Letcher, A. J. and Dawson, R. M. (1984) Phosphatidylinositol4,5-bisphosphate phosphodiesterase and phosphomonoesterase activities of rat brain. Some properties and possible control mechanisms. Biochem. J. 218, 177-185

16 Streb, H. and Schulz, I. (1983) Regulation of cytosolic free $\mathrm{Ca}^{2+}$ concentration in acinar cells of rat pancreas. Am J Physiol. 245, G347-357

17 Downes, C. P., Mussat, M. C. and Michell, R. H. (1982) The inositol trisphosphate phosphomonoesterase of the human erythrocyte membrane. Biochem $\mathrm{J}$. 203, 169-177

18 Berridge, M. J. (1985) The molecular basis of communication within the cell. Sci Am. 253, 142-152.

19 Streb, H., Irvine, R. F., Berridge, M. J. and Schulz, I. (1983) Release of Ca ${ }^{2+}$ from a nonmitochondrial intracellular store in pancreatic acinar cells by inositol1,4,5-trisphosphate. Nature. 306, 67-69

20 Dawson, R. M., Freinkel, N., Jungalwala, F. B. and Clarke, N. (1971) The enzymic formation of myoinositol 1:2-cyclic phosphate from phosphatidylinositol. Biochem J. 122, 605-607

21 Wilson, D. B., Bross, T. E., Sherman, W. R., Berger, R. A. and Majerus, P. W. (1985) Inositol cyclic phosphates are produced by cleavage of phosphatidylphosphoinositols (polyphosphoinositides) with purified sheep seminal vesicle phospholipase C enzymes. Proc Natl Acad Sci U S A. 82, 4013-4017

22 Grado, C. and Ballou, C. E. (1961) Myo-inositol phosphates obtained from alkaline hydrolysis of beef brain phosphoinositide. J.Biol. Chem. 236, 54-60

23 Tomlinson, R. V. and Ballou, C. E. (1961) Complete characterisation of the myo-inositol polyphosphates from beef brain phosphoinositide. J. Biol. Chem. 236, 1902-1906

24 Frahn, J. L. and Mills, J. A. (1959) Paper ionophoresis of carbohydrates. I. Procedures and results for four electrolytes. Aust. J. Chem. 12, 65-89

25 Irvine, R. F., Brown, K. D. and Berridge, M. J. (1984) Specificity of inositol trisphosphate-induced calcium release from permeabilized Swiss-mouse 3 T3 cells. Biochem. J. 222, 269-272

26 Folch, J. (1949) Brain diphosphoinositide, a new phosphoinositide having inositol metadiphosphate as a constituent. J. Biol. Chem. 177, 505-519

27 Burgess, G. M., Godfrey, P. P., McKinney, J. S., Berridge, M. J., Irvine, R. F. and Putney, J. W., Jr. (1984) The second messenger linking receptor activation to internal $\mathrm{Ca}^{2+}$ release in liver. Nature. 309, 63-66

28 Dawson, A. P. and Irvine, R. F. (1984) Inositol (1,4,5)trisphosphate-promoted $\mathrm{Ca}^{2+}$ release from microsomal fractions of rat liver. Biochem Biophys Res Commun. 120, $858-864$

29 Prentki, M., Biden, T. J., Janjic, D., Irvine, R. F., Berridge, M. J. and Wollheim, C. B. (1984) Rapid mobilization of $\mathrm{Ca}^{2+}$ from rat insulinoma microsomes by inositol 1,4,5-trisphosphate. Nature. 309, 562-564

30 Brown, J. E., Rubin, L. J., Ghalayini, A. J., Tarver, A. P., Irvine, R. F., Berridge, M. J. and Anderson, R. E. (1984) myo-Inositol polyphosphate may be a messenger for visual excitation in Limulus photoreceptors. Nature. 311, 160-163 31 Fein, A., Payne, R., Corson, D. W., Berridge, M. J. and Irvine, R. F. (1984) Photoreceptor excitation and adaptation by inositol 1,4,5-trisphosphate. Nature. 311, $157-160$

32 Whitaker, M. and Irvine, R. F. (1984) Inositol 1,4,5-trisphosphate microinjection activates sea urchin eggs. Nature. 312, 636-639 
33 Berridge, M. J. and Irvine, R. F. (1984) Inositol trisphosphate, a novel second messenger in cellular signal transduction. Nature. 312, 315-321

34 Irvine, R. F., Letcher, A. J., Lander, D. J. and Downes, C. P. (1984) Inositol trisphosphates in carbachol-stimulated rat parotid glands. Biochem. J. 223, 237-243

35 Irvine, R. F., Änggård, E. E., Letcher, A. J. and Downes, C. P. (1985)

Metabolism of inositol 1,4,5-trisphosphate and inositol 1,3,4-trisphosphate in rat parotid glands. Biochem J. 229, 505-511

36 Downes, C. P. and Wusteman, M. M. (1983) Breakdown of polyphosphoinositides and not phosphatidylinositol accounts for muscarinic agoniststimulated inositol phospholipid metabolism in rat parotid glands. Biochem J. 216, 633-640

37 Hesketh, R. (1983) Inositol trisphosphate: link or liability? Nature. 306, 16-17

38 Burgess, G. M., McKinney, J. S., Irvine, R. F. and Putney, J. W., Jr. (1985)

Inositol 1,4,5-trisphosphate and inositol 1,3,4-trisphosphate formation in $\mathrm{Ca}^{2+}$ mobilizing-hormone-activated cells. Biochem J. 232, 237-243

39 Batty, I. R., Nahorski, S. R. and Irvine, R. F. (1985) Rapid formation of inositol 1,3,4,5-tetrakisphosphate following muscarinic receptor stimulation of rat cortical slices. Biochem. J. 232, 211-215

40 Irvine, R. F., Letcher, A. J., Heslop, J. P. and Berridge, M. J. (1986) The inositol tris/tetrakisphosphate pathway - demonstration of $\operatorname{Ins}(1,4,5) \mathrm{P}_{3} 3$-kinase activity in animal tissues. Nature. 320, 631-634

41 Irvine, R. F., Letcher, A. J., Lander, D. J., Heslop, J. P. and Berridge, M. J. (1987) Inositol(3,4)bisphosphate and inositol $(1,3)$ bisphosphate in GH4 cells-evidence for complex breakdown of inositol $(1,3,4)$ trisphosphate. Biochem Biophys Res Commun. 143, 353-359

42 Shears, S. B., Parry, J. B., Tang, E. K., Irvine, R. F., Michell, R. H. and Kirk, C. J. (1987) Metabolism of D-myo-inositol 1,3,4,5-tetrakisphosphate by rat liver, including the synthesis of a novel isomer of myo-inositol tetrakisphosphate. Biochem J. 246, 139-147

43 Stephens, L., Hawkins, P. T., Carter, N., Chahwala, S. B., Morris, A. J., Whetton, A. D. and Downes, P. C. (1988) L-myo-inositol 1,4,5,6-tetrakisphosphate is present in both mammalian and avian cells. Biochem J. 249, 271-282

44 Whitman, M., Downes, C. P., Keeler, M., Keller, T. and Cantley, L. (1988)

Type I phosphatidylinositol kinase makes a novel inositol phospholipid, phosphatidylinositol-3-phosphate. Nature. 332, 644-646

45 Stephens, L. R. and Irvine, R. F. (1990) Stepwise phosphorylation of myoinositol leading to myo-inositol hexakisphosphate in Dictyostelium. Nature. 346, 580583

46 Heslop, J. P., Irvine, R. F., Tashjian, A. H., Jr. and Berridge, M. J. (1985) Inositol tetrakis- and pentakisphosphates in GH4 cells. J Exp Biol. 119, 395-401 47 Cullen, P. J., Hsuan, J. J., Truong, O., Letcher, A. J., Jackson, T. R., Dawson, A. P. and Irvine, R. F. (1995) Identification of a specific $\operatorname{Ins}(1,3,4,5) \mathrm{P}_{4}$-binding protein as a member of the GAP1 family. Nature. 376, 527-530

48 Schurmans, S., Polizzi, S., Scoumanne, A., Sayyed, S. and Molina-Ortiz, P. (2015) The Ras/Rap GTPase activating protein RASA3: from gene structure to in vivo functions. Advances in biological regulation. 57, 153-161

49 Mitchell, J., Wang, X., Zhang, G., Gentzsch, M., Nelson, D. J. and Shears, S. B. (2008) An expanded biological repertoire for Ins $(3,4,5,6) \mathrm{P} 4$ through its modulation of ClC-3 function. Curr Biol. 18, 1600-1605 
50 Shears, S. B. (2004) How versatile are inositol phosphate kinases? Biochem J. 377, 265-280

51 Wilson, M. S., Livermore, T. M. and Saiardi, A. (2013) Inositol pyrophosphates: between signalling and metabolism. Biochem J. 452, 369-379 52 Millard, C. J., Watson, P. J., Celardo, I., Gordiyenko, Y., Cowley, S. M., Robinson, C. V., Fairall, L. and Schwabe, J. W. (2013) Class I HDACs share a common mechanism of regulation by inositol phosphates. Mol Cell. 51, 57-67 53 Balla, T. (2013) Phosphoinositides: tiny lipids with giant impact on cell regulation. Physiol Rev. 93, 1019-1137 


\section{Figure Legends}

Figure 1

Inositol phosphates from carbachol-stimulated rat parotid slices.

The first indications that inositol phosphate metabolism might be more complicated than we had thought. This Figure is reproduced from ref [34], though the experiment was performed in the summer/autumn of 1982 - see text. It shows the separation of $\left[{ }^{3} \mathrm{H}\right]-$ inositol phosphates (open circles) extracted from carbachol-stimulated rat parotid slices on a Pharmacia fplc column. The triangles (left) are an internal Ins $P$ standard (mostly Ins $2 P)$, and the black circles are a mixture of $\left[{ }^{32} \mathrm{P}\right]-\operatorname{Ins}(1,4) P_{2}$ and $\left[{ }^{32} \mathrm{P}\right]-\operatorname{Ins}(1,4,5) P_{3}$ prepared from red cell membranes. The Ins $P_{3}$ peaks labelled with the two isotopes (right) do not co-chromatograph exactly.

\section{Figure 2}

Specificity and stoichiometry of $\operatorname{Ins}(1,4,5) P_{3}$-stimulated $\mathrm{Ca}^{2+}$ release (free $\mathrm{Ca}^{2+}$ measured by a $\mathrm{Ca}^{2+}$ electrode) from permeabilised pancreatic cells (rat).

This is a photocopy of an unpublished experiment performed by Hans-Peter Streb and Irene Schulz in late November 1983. For the experimental protocol see ref [19], but in brief, a permeabilised cell preparation is added to the buffer (which includes ATP), and the free $\mathrm{Ca}^{2+}$ levels drop (and so pCa rises) as $\mathrm{Ca}^{2+}$ is pumped into the intracellular stores (left). The axis is adjusted and then subsequent additions of $\operatorname{Ins}(1,4) P_{2}$ or $\operatorname{Ins}(4,5) P_{2}$ (both at successively $1 \mu \mathrm{M}$ and $5 \mu \mathrm{M}$ ) have little effect, but $1 \mu \mathrm{M} \operatorname{Ins}(1,4,5) P_{3}$ causes a large release of $\mathrm{Ca}^{2+}$. An additional (and important) conclusion from this experiment is that, as judged by the calibrating 10 nmoles $\mathrm{Ca}^{2+}$ (right), around $30 \mathrm{nmoles}$ of $\mathrm{Ca}^{2+}$ are released by 3 nmoles $(1 \mu \mathrm{M}$ in $3 \mathrm{ml})$ of $\operatorname{Ins}(1,4,5) P_{3}$ so the effect of $\operatorname{Ins}(1,4,5) P_{3}$ on $\mathrm{Ca}^{2+}$ release is catalytic.

Figure 3

The formation of $\operatorname{Ins}(1,3,4) P_{3}$ and $\operatorname{Ins}(1,3,4,5) P_{4}$.

This Figure is reproduced from ref [40], which postdates this account, but it illustrates its denouement. Note the speculation that $\operatorname{Ins}(1,4) P_{2}$ is the breakdown product of $\operatorname{Ins}(1,3,4) P_{3}$, which we later found to be incorrect [41]. 
Figure 1

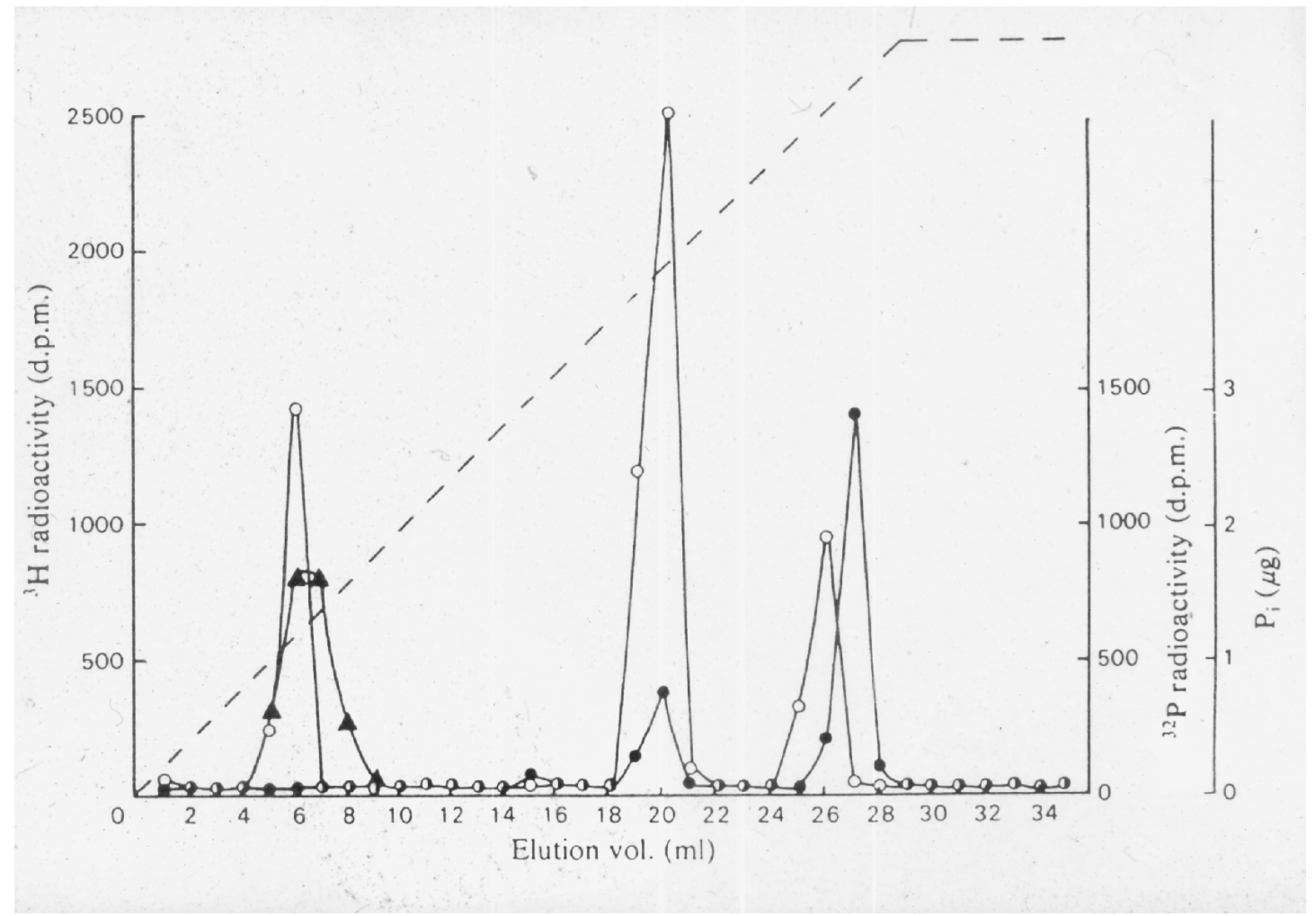


Figure 2

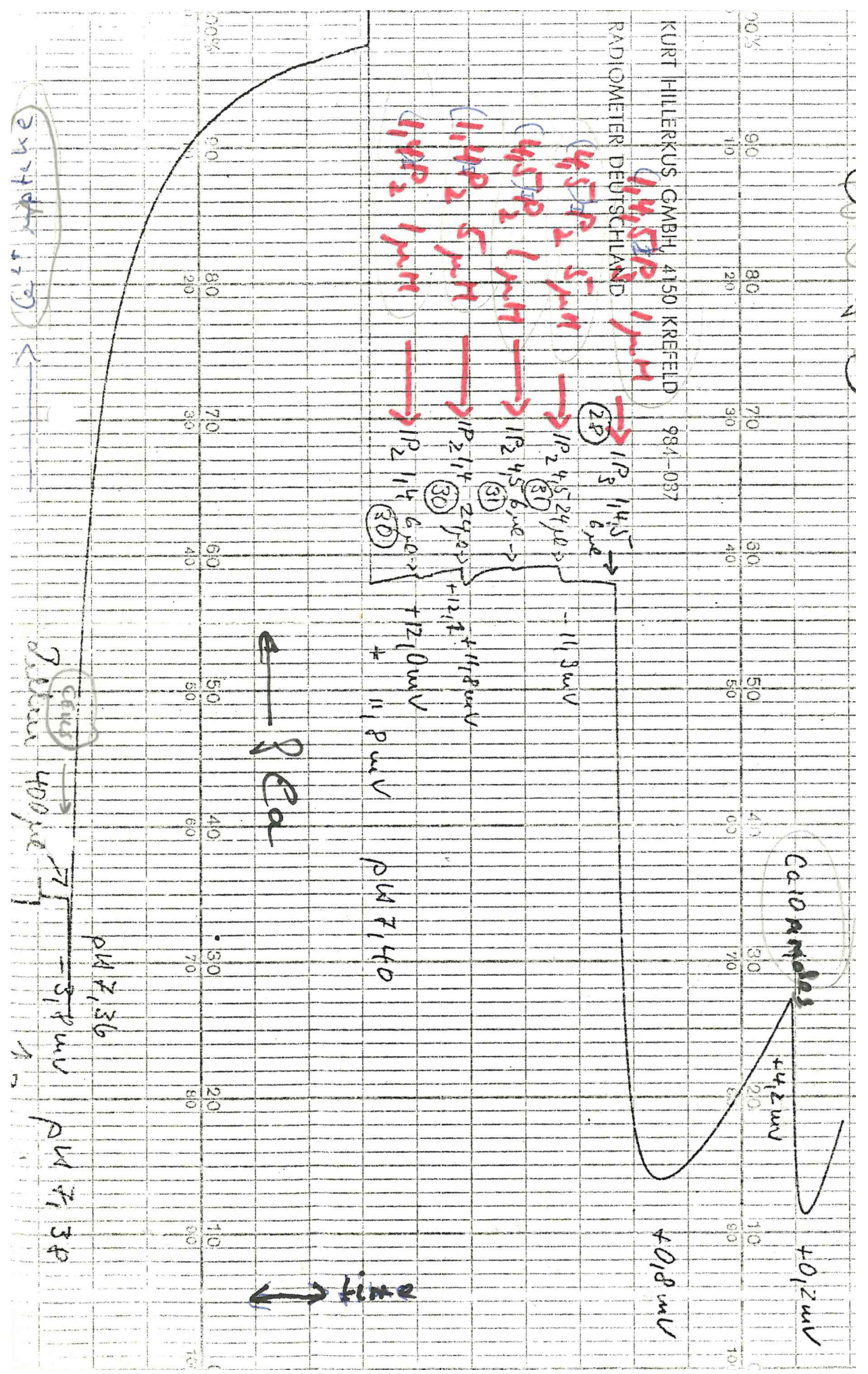


Figure 3

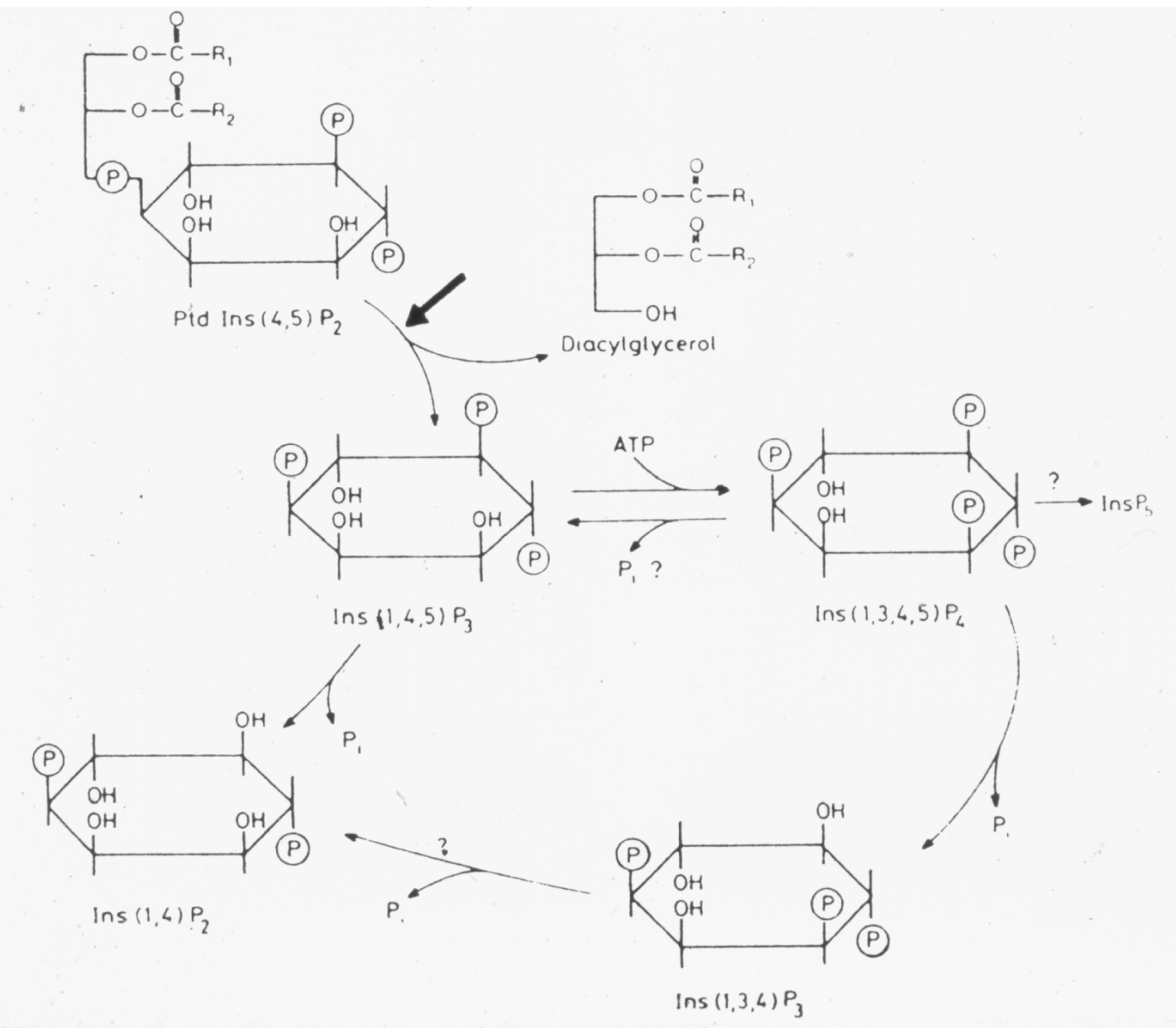

